\title{
THE IMPACT OF BLOOD COVENANT ON DEVELOPMENT IN NIGERIA
}

\author{
Emmanuel J. Ibuot* \\ http://dx.doi.org/10.4314/og.v10i 1.6
}

\begin{abstract}
Every human gathering is a function of various individuals but if such an assembled group must form a functionally cohesive unit, then the members of the group must be in a covenant/pact. The presence of pact distinguishes a society from other gathering of human beings. Some societies are more productive and progressive than others because of the treaty/covenant in operation. In 21st century Nigeria, it has been noticed that apart from the national document covenanting the various peoples of Nigeria, The Constitution of the Federal Republic of Nigeria, some alternative pact exists, namely blood covenant. The latter has come to the fore because of a version of it, namely blood covenant of the esoteric type. Being highly cryptic in nature, and seeing that it commands robust allegiance parallel to that demanded by the national covenanting document, can societal development be predicated upon it? In this paper, it is argued that this rival covenant has a tendency of forcing society into the pathway that eludes visibility, open assessment, and accountability, which characterizes open society. Nigeria and her leaders must move away from this cryptic pact if society must not be run aground by parallel allegiance.
\end{abstract}

\section{Introduction}

It is said that no man is an Island; that every human being needs the company of other persons if he/she must survive meaningfully. One may quickly object by raising the lives of hermits as men and women, who live without need of other human beings. But this instantiation is raised due to a lack of understanding of hermitic conditions. The hermit may live alone for a long time but not totally without men since he must need assistance from other people. For instance, he cannot supply all his material needs in life. The hermit lives a life wholly dedicated to God, which does involve, among other things praying for his fellow men and women in the world. He 
cannot disconnect himself from mankind as such. So, we cannot escape being involved in horizontal relationships, which involves human beings. For this reason, man, in the generic sense, is called a social being. Apart from the horizontal plane, man does enter into vertical relationships (relating with God and at times, with other spirits) as evidenced by man's continuous interests in things supernatural as found in Judaeo-Christian ideology and in African Traditional Religion.

Entering into relationship with other human beings is fraught with challenges. Relationship is a very fragile reality in that two friends, who are known to form pleasant companionship in public - smiling away, hugging with reckless abandon, sacrificing their study time just to be there for the other person, who may be emotionally dependent on him/her, et cetera - may turn into the bitterest of enemies and traitors ever penned the following day. Why? Human nature seems to be terribly selfish and fallible in that it is prone to withdraw from any relationship if one's self interest is not protected; it is 'terrible' on the basis that the human person naturally tilts towards self-preservation. ${ }^{1}$ It is on the ground of being responsive to the principle of self-preservation that it is illogical to expect a human being to desire self-harm. Man is 'fallible' because, like Kant argued, he cannot know a thing-in-itself or reality in its completeness due to the shortness of his life and the finitude of human cognitive ability. ${ }^{2}$ Philosophy and its logical postulations do not have a response to this enigma; it cannot compel people to stay in any relationship against the drive of personal gratification neither does it have any compelling force because the purported force of rational argumentation fails in the face of the principle of selfpreservation and deep passion. So, logic is not strong enough to compel people unto faithfulness in relationships. Professors and academics of diverse expertise have been known to fail in marital relationships notwithstanding their expertise in assorted fields of physical and human/behavioural sciences. In other words, not even the theories of academic disciplines, inspired by the borders set by the empirical sciences' idea of objective knowledge ${ }^{3}$, can furnish human beings with the capabilities that guarantee fruitful relationships. There is more to life than academic discourses.

Many persons ['person(s)' as used in this article 
encapsulates individual human beings, corporate entities, nations, and divine beings] have suffered physical and psychological abuses in the course of relating with other human beings, including death. For this reason, a lot of persons have devised ways of avoiding interpersonal engagement, an impracticable imagination. ${ }^{4}$ Several attempts have been devised to stem the negative experiences of men and women in interpersonal contexts. One of these attempts is called covenant. In this paper, the author examines different senses and structures of covenants and their functionality.

\section{Understanding Covenant in Diverse Cultures}

A covenant is an agreement between at least two parties that may be individual persons, companies, villages, nations, et cetera. It is an agreement that is very solemn in nature and usually involves an oath to indicate the predisposition of the parties to make good on their words. This solemn agreement is also legal in nature, which is the reason covenants usually include blessings (benefits) and curses (loses). According to G.E. Mendehall, a covenant is,

a solemn promise made binding by an oath, which may be either a verbal formula or a symbolic action. Such an action or formula is recognized by the parties as the formal act which binds the actor to fulfil his promise. ${ }^{5}$

Whether the word 'covenant,' 'pact,' 'testament,' 'will,' 'bequest,' 'treaty,' 'alliance,' et cetera is used, it is the same matter that is meant.

Getting different persons into workable relationships that involve both duties/obligations and benefits (these two dimensions are found in covenants), dates back to ancient times. Covenants have been found to exist among ancient cultures like the Hittites ${ }^{6}$, Africans ${ }^{7}$, Jews ${ }^{8}$, et cetera. This implies that the desire for security in relationships may be said to be as old as man. This conclusion is built on the foundation of the principle of self-preservation, which no man can be said not to experience. Human beings want to live, yet they have a certain fear and dread of death as annihilation. They desire to cling unto life and avoid what would threaten their lives 
including that of other people. So, men seek the security of their lives and their appendage; the desired security includes their biological lives, material (economic) possessions, intellectual, spiritual, and emotional/psychological lives. Relating with other persons is a vulnerable exercise. By opening oneself to another person whether it is in terms of one's strengths or weaknesses, one actually arms that person to become his/her potential destroyer. Intimate relationships therefore do appear to need the security of covenants.

A covenant may exist between individual human beings, say Mr. John and Miss Jane, who cut their own blood, mingle it together and lick it up while they swear to love each other by marrying no other person but themselves; between two or more nations, say Nigeria joining other nations in signing an agreement to defend some rights in the forms of the International Covenant on Civil and Political Rights (ICCPR) and the International Covenant on Economic, Social and Cultural Rights (ICESCR); between one village and its neighbour, say the two village heads using the blood of human beings or some animals to bind themselves in agreement never to harm any member of either village, which failure must draw negative consequences on the defaulting party as stated in the articulation of the covenant (the curses that were pronounced); between individual human beings and/or villages with some spiritual beings in the forms of preternatural forces such as earth goddesses, sun-god, god of the sky, fertility-goddesses, village deities, community deities et cetera (as found in polytheistic religious systems) or the supernatural force called El Shaddai as seen in the case of Judaeo-Christian system" where "your creator shall be your Husband" (Isaiah 54: 5) and "the marriage of the Lamb has come, and his bride has made herself ready" (Rev. 19: 7).

Interviewing a man, Mr. Festus Abbah ${ }^{10}$, I found out that it is common knowledge among the people of Amallah that young men and women do cut their flesh and mingle their blood in blood-oath to stay in love and marry each other. Whenever any of the two parties default, very bad things are known to occur such as madness and death. Among the Ibibio people of Nigeria, just like other tribes in Nigeria, we find that when a baby is born and there appears to be any persistent health challenge, the child is taken to some expert in 
the community to incise or cut open some parts of the child's face, chest, back, shoulder, et cetera, which allows blood to trickle out and dark powder like gun-powder or soot from a lantern is rubbed in (while some words are pronounced). In this way, the child is placed under the protective arms of whatever spiritual entity was invoked. And it did seem to work for them except that the passage of time has revealed other consequences not imagined as at the time. A critic may wonder how reasonable it is to imagine a linkage between words (like covenant-oaths and ritual utterances) and effect (say sickness, madness, and death). It may be asked if words produce and/or influence acts. In traditional African communities, this type of question was not entertained because it was taken for granted that words produce acts: for example, the pronouncement of a curse by a Chief Priest, who was seen as a "...servant of a deity"11 and a sharer in "the nature of deity"12 is believed to be efficacious in producing the negative effects on the person to whom the curse is directed unless some other operations - ritual ceremonies - were performed to avert that verbal action. According to J. L. Austin, in How to Do Things with Words, there is a type of speech performance which does produce effect that occurs outside the speech itself, and affects those who hear it. It is called perlocutionary act. Ritual utterances and oaths (including covenant-oaths) belong to this category of acts. ${ }^{13}$ So, against the Humean suggestion of a necessary connection between cause and effect, J. L. Austin's position suggests that life is more than material entities and may not be examined by the Humean thesis, and that it is reasonable to argue that words can be connected to action/effect. In cultures that put a premium on virginity such as Islam, Judaism, Christianity and some traditional societies, before a marriage agreement was concluded, the two families loved to get a report that the girl had not been deflowered; this they ensured by insisting that the two partners consummated their marital union by knowing each other on a white sheet or linen. Now, if the sheet was stained with blood after the encounter, then they had proof of the lady being a virgin. Whether this method was full-proof of virginity is not really the subject of this discourse, but blood covenant. It does appear that marriage between a man and a woman was built by God the Creator to be a secure system. A virgin usually has a hymen, which is an organization of blood-carrying and sponge-like tissues, 
fleshy membrane that on contact with the male sexual organ specific becomes compromised and lets out blood. Thus, the entry of the male into the female system was meant to receive the baptism of blood. In my opinion, the man and woman are bound by blood. Sex is blood-union; marriage is blood-union. Every other sexual union, thus, is done in the background of initial release of blood. Blood announces the entry of the male and becomes the basis of appreciating further encounters. It brings us to understand that two lives have been mingled. The Judaeo-Christian thesis runs thus: "for the life of the flesh is in the blood" (Lev. 17:11). Sexual encounters are blood encounters and blood encounters are covenants (of lives) on the basis of blood as security or guarantee with God as the witness and the arbiter. On the basis of the security it provides, a security that borders on pleasure or pain (pleasure, if one stays faithful or pain, if one defaults), other kinds of unions like male to male, and female to female unions (what some people call 'same-sex marriage') are outlandish and unacceptable. They have no in-built protection or security mechanism for the physical, emotional/psychological, financial (economic), and spiritual angles of the lives of the individuals. These dimensions of the lives of the human persons in the covenant are crucial and very sensitive, and need protection since in relationships like marriage people by opening up themselves to their partners are very vulnerable. They are vulnerable because by opening themselves, they trust their private lives to the other party, and the other person can use it for or against them. This is where the question of verbal trust has been found to be inadequate in serving as a secure basis for entrusting one's private details to an alter ego, another self. It is the failure to have relationships with in-built provisions and conditions that forces each of the parties to a relationship to protect the private life of the other that necessitates the 'angst' (dread) that keep many persons from daring to enter into close relationship with others. This experience is not peculiar to Africans; it is rife among the westerners. According to Farfaglia in Man to Man: A Real Priest Speaks to Real Men about Marriage, Sexuality and Family Life,

Most single men and women are terrified about getting close to anyone. Most single people are 
suspicious about anyone who wants to be a true friend. Most Americans have shut down emotionally and socially. They have become isolated and incapable of friendship. ${ }^{14}$

Among the people of Western Uganda, specifically Nyoro, a covenant is established between two persons seeking stronger ties. The elder moderating the ritual cuts open the abdominal and heart regions of both parties such that little blood can ooze out. He takes a coffee bean, breaks it open, and smears it with the blood of each of the parties. He gives each of the halves with the blood of the other party to the covenant to be swallowed. Then, they pronounce,

as we have become friends, let the stomach of whoever cheats his friend swell. When I visit you, at any time, you will not send me away. If I become poor you will not discard me. We will never do anything to harm any of our relatives and friends. May our ancestors be our witnesses. May God ratify our friendship, our brotherhood. ${ }^{15}$

From the foregoing, we can recognize that people enter into covenants for various reasons such as guaranteeing faithfulness, protection and unity. It is also clear to us that some covenants involve blood while others do not involve blood. People tend to flinch from breaking covenants that involve blood as observed in the cases of Nyoro cited above and of the Amallah report, of young people in love, who mingle their blood (and, at times, lick the blood) and swear to stay and marry only themselves and no other person. As for covenants that do not have blood in it such as trade pacts, political alliances, and military treaties between nations in contemporary times, which are generally sealed on paper and followed through by means of diplomacy, or by military force if need be, experiences have demonstrated that nations have broken away from such agreements when it did affect their interest(s). For example, the Kyoto Protocol, a bloodless covenant, is an agreement that was reached in 1997 to cut gas emissions by $5 \%$ between 2008 and 2012. The western nations have failed to meet this fringe 
commitment of 5\% because it may hurt their economies; and 2012 has come and gone. ${ }^{16}$ Rather than cut their emissions so as not to exceed their carbon credits, they came up with a fanciful mechanism of trading carbon credits. It is called clean development mechanism: countries that must meet emission targets choose to pay developing countries, which have lower emissions not to emit more gases by using cleaner technology. The truth is that the developing nations are being hoodwinked to stay at their current developmental level. Is it the developing nations that have the cleaner technology that the West do not yet have or may be trying to develop? All court marriages, too, are bloodless covenants. They are devoid of any inbuilt guarantee (like Judaeo-Christian marriages whereby the partners promise commitment to each other, which they seal with the taking of Holy Communion i.e. blood covenant in the form of the Body and Blood of Jesus). It is this involvement of blood as the seal of two persons in marriage that causes the Church to state that once marriage is sealed, it is irrevocable, and so divorce is not an option afterwards. In Malachi 2: 14-16, God declares that He is the witness to the marriage agreement, which demands faithfulness/trust, and kicks out the possibility of divorce,

...he now refuses to consider the offering or to accept it from you. And you ask, "Why?" Because Yahweh stands as witness between you and the wife of your youth, with whom you have broken faith, even though she was your partner and your wife by covenant...Have respect for your own life then, and do not break faith with the wife of your youth. For I hate divorce, says Yahweh, God of Israel, and people concealing their cruelty under a cloak, says Yahweh Sabaoth. Have respect for your own life then, and do not break faith. ${ }^{17}$ (bold is mine)

It is interesting to note here how the above passage twice suggests death (see the highlighted portions). Death is presented as the punishment for divorce, cruelty and unfaithfulness to one's covenant partner.

In blood covenants, generally, whether it involves the 
preternatural forces found in African Traditional Religion (ATR), or the supernatural force of Judaeo-Christian ideology, there are three parties to a covenant: the two human beings and a higher authority that hold them to account as it relates to their commitments. This third party is the spirit(s)/'gods' of ATR or El Shaddai of JudaeoChristian system.

Court marriages fail the most since it has no deterrent structure. Any party can pull out on the basis of any reason that he/she thinks is cogent. On this type of basis, no one can build a truly solid and organic society, which needs functional families at its roots. Ogbuelli notes,

The foundation for the society is the family but the foundation for the family is the marriage institution. Therefore, when a society loses marital values, family values collapse and the result is the decay of the moral fabric of the society. So...the moral state of a nation and its societal values reflect the values it holds of the marriage institution. ${ }^{18}$

There exists a seemingly envious peace and order in the West but it is the peace of serious policing; these societies are policed states. This strongly suggests that the peace within Western societies is not borne out of voluntary adherence to the law but by subtle coercion or force in the form of the law and the police. Policing is in the frontline of our understanding of Western social organization because of the rise in crime such as serial killings, rape, child abuse, financial fraud (tax evasion is an instance), robbery, illegal trafficking of women and children, attacking and stealing from the elderly, school shootings and mass murder (like the Tucson shooting of 2011). These ills may be said to besiege the West because the foundation of its societies, the family is collapsing, it totters. It crumbles on account of the shaky foundations of the marital unions; the marriages designated civil, set up by civil courts, are manifestly the weakest - they can be undone by as much as a signature for any reason by any of the spouses. It does not encourage commitment that may endure since the possibility of exiting it exists from the onset. But commitment to a long-term affair is certainly compromised by 
the availability of an easy exit corridor. Apart from civil marriages, Christian marriages have generally suffered from divorce though not with the ease of civil marriage dissolution. Yet, the divorce rate in regards to Christian marriages today may stand at an all-time high when juxtaposed with that of the West of 100 years ago. The reason does not necessarily lie in Christianity but with growth in adoption of secularism, relativism, and hedonism, offshoots of humanism (the outlook that man is the acme of existence) that gained pre-eminent articulation and popularization during the Enlightenment period. Nevertheless, some elements of it are traceable to ancient Greek philosophy (in the thoughts of Protagoras for instance) and beyond the Enlightenment to contemporary Western philosophy. This movement from Christianity (and its profession of moderation of human appetite in the form of ascetical practices) to humanism may jolt any person, who considered Christianity as the foundation of Western culture (a typical outlook of someone who views culture as a static phenomenon, as "the way of life of a people"). The history of Christianity is not coterminous with that of the West; it has its origins amongst the Semitic people, particularly the Jews. Identifying Christianity with the West is one of the distortions of history propagated through Chinweizu's writings, especially The West and the Rest of Us. Before the entry of Christianity into the West, nature-worship was predominant. Christianity may be said to have greatly dislodged the traditional religions of Europe so much that it seemed coterminous with European history; we may say it is coterminous with the rapid development of the West more than other continents of the world. ${ }^{19}$ Yet, as contemporary Europe downplays the Judaeo-Christian ideology that once enabled it forge social cohesion in a once belligerent continent, we find her resort more and more to policing to maintain social order, at times at a great price. But it may be queried that not everybody has abandoned Christianity for humanism (secularism, relativism, and hedonism). It is a fact that many divorced spouses and some spouses, who consider divorce or marital dissolution as an option, still identify themselves as Christians. This seems contradictory from the standpoint of JudaeoChristian ideology. It might be that they had understood Christian marriages as contracts instead of covenants. While contracts are transient in nature and about the exchange of goods and services, 
covenants are irrevocable and concerns the exchange of persons. ${ }^{20}$ In other words, covenants create tend to encourage relational security. Love, which guarantees the healthy development of children, cannot function in an insecure environment. For this reason, Jane Rubey posits that "all relationships that lead to love and the nurturing of children are a valuable source of strength and unity in our social fabric." 21

\section{Blood Covenants in Politics and Development}

It is an open secret in Nigeria that office holders like the Governors indulge in occultism and now, we know with surety that they command loyalty from the people they bring in as their co-workers by first coercing them to take special oaths of allegiance to them before some traditional deities and shrines as distinct from the constitutional provisions on oath-taking for public officers. In 2003, the story of the former Governor of Anambra State, Chris Ngige and the Okija Shrine was the first example that destroyed the veneer of respectability that hung around our educated politicians. Governor Theodore Orji of Abia State's nude picture before a specific shrine in 2007 was the next to support the role of the esoteric in Nigerian politics. As usual, some arguments were put forward to justify and/or deny the data on the dailies. All these revealing events centred on the eastern part of Nigeria until recently when the music moved to the western part of Nigeria with the Ogun State Governor, Gbenga Daniel and Hon. Wale Alausa, Honourable Member of the Ogun State House of Assembly, who confessed about entering into a blood covenant with Governor Daniel. ${ }^{22}$ Just like the cases of Dr. Chris Ngige and Theodore Orji, the Ogun Shrine came to limelight because one party to the oath felt betrayed. To compel the erring covenant-partner to defend his principal, the offended resorted to engaging the offending party by embattling his psyche - exposing his nude picture in regard to a shrine. The point of interest in this discourse on 'Blood Oath Scandal' has nothing to do as such with their denials and justifications, but the question of parallel principles of allegiance and statehood, namely the Constitution of the Federal Republic of Nigeria and the privately-driven blood covenants. Do these parallel principles meet?

There appears to be no arrangement in Nigeria that is 
considered most binding and deadly in compulsion like the demands of blood oaths. The belief in the force of blood-oaths is still rife in the minds of contemporary Nigeria's rationally trained leaders such that blood oaths are held in higher esteem than the bloodless oaths provided by the Constitution of the Federal Republic of Nigeria.

In known traditional cultures, blood covenants or oaths were common; it formed the basis of primitive religions and societies. Different traditional societal groups ceased to war against each other on the basis of the blood covenants that were made between both villages. It was sacred and respected so much that the covenantal terms were strictly adhered to under the pain of disastrous consequences, which includes death. ${ }^{23}$ From this light, one can appreciate the position of Hon. Alausa, a Nigerian politician, who would not join ranks against Governor Daniel lest the curses for breaking the blood oath came upon his son whose life he pledged as guarantee that he would not go against the Governor. Rather than honour the constitutional provisions on safety and fulfil his civic duty like impeaching the Governor, if he deserves that discipline, he would rather honour a blood oath without recourse to the public oath he swore on assumption of office. Could it be that the blood oath only has a psychological effect since Ngige and Orji did not suffer the deadly consequences due to contraveners of blood oaths? It may be difficult to give a neat answer to this question owing to the fact that one angle of the covenant is esoteric and so, is lost to secrecy between the spirit-beings, the priest, and the covenanting human being(s). Yet, it seems to have failed not because it is merely psychological as the Amallah interview earlier mentioned attests but because of two possibilities: i) the priest, who may be a fraudster, out on a profiteering mission, and ii) a culprit, who exploits the option of appeasing the said 'spirits' at work in the form of invoking the principle of substitution - another life (human or animal) or object may be given in the place of the original person, who should have borne the consequences of defaulting on a covenant; this substitute becomes the bearer of the consequences or supplies what should have been lost by the original defaulter on account of breaching an agreement. It seems that this is made possible by the advice of either the same priest or another priest, very knowledgeable of such intricate art and negotiations. This again 
suggests that the possibility of huge material gains may inform the readiness of a traditional religious priest to support such appeasement ritual, which tends to insulate the defaulter from his/her due consequences.

The people slaughtered and divided into various parts as animals with price tags at Jankara Market ${ }^{24}$ were some of Nigeria's potential leaders: inventors, politicians, business persons, educationists, et cetera. The Constitution of the Federal Republic of Nigeria cannot work while these types of atavistic rules remain unchallenged. The West arrived at the point of development, which has kept her in the leadership seat of the world, was enabled by the introduction of a novel ideology - one that was different in structure and form from the then prevalent magical and esoteric-supporting systems, which were akin to the ones in Nigeria just presented above. The introduction and popularisation of the Christian Outlook in the West was the joker against the inhuman and undignified practices advanced by their earlier magical, ethical and religious systems. $^{25}$

Nigeria has failed to actualize her potentials because no functional official covenant (blood or bloodless) exists between her composite nations or linguistic units. The constitution is supposed to encapsulate the terms and conditions for the mutual existence of her members. There may be covenants within each of the ethnic groups but no inter-ethnic binding agreement exists between all the ethnic groups in the country whether orally made or written. No accounts exist to the counter. If Nigeria must survive, then an inter-ethnic covenant-making meeting must be convoked to discuss and set in motion a proper basis for any functional nation. The absence of this type of agreement is the raison d'être for the persistent crises within and between the apparently united nations in Nigeria particularly and in Africa generally, and the inordinate desire to perpetuate oneself in power. Some of these nations/countries have existence that were not negotiated but were forcefully generated by colonists. These types of organizations stand in contradistinction to the mode of operation of issues at the international level where all kinds of covenants exist with their memorandums of understanding whether blood-based or not.

Before the assumption of office, the political office holders 
take oaths of allegiance to the people of the state based on a public code, the Constitution of the Federal Republic of Nigeria. The saga of blood oaths reveals that the governors and other office holders do enter into counteractive oaths of allegiances ${ }^{26}$, which depicts their conviction that the provisions of the blood oaths take precedence over the law of the land, the Constitution of the Federal Republic of Nigeria. If the supposed leaders of thought casts slur on the law of the land, who then is bound to obey it? The Nigerian constitution is based on positivism and rationalism, which definitely rejects entities outside the region of mental objects as irrational. This positivist and rationalist constitution cannot work simultaneously with the nonrationalist blood oaths. For one of either the Constitution or bloodoaths to be in operation and be duly obeyed, one of them must be suspended. Thus, we witness that one of the reasons the Constitution of the Federal Republic of Nigeria has not worked properly is because it has been suspended for a highly valued and trusted mechanism of control (namely blood oath/covenant) to run its course. From these findings, it can be simply inferred that we are ruled by occult-controlled personalities, denizens of the esoteric realm, ritual killers and their sponsors. This explains the reason for the failure of the various theories, principles, policies, et cetera known to have worked in similar situations for which they were meant to address in other nations. This problem is rooted in the debacle of traditional Nigerian ideology as found in our traditional ethical and religious belief systems.

In traditional African religion, jungle justice seems to be the operational law; the fittest survives. The spirit-forces, which are the models for men and women, never sacrifice themselves. Although they are supposedly higher than human beings and dictate the rules of living for men via its priests, they choose to receive human sacrifices. This is the case of the dictatorship of the strong that lays the foundation for the culture of impunity prevalent among political rulers, who can easily rationalize that they are the society's priests just like St. Simon conceived the guardian of society - the Aristocratic class. ${ }^{27}$

Nigeria has lost several millions of Naira to blood pact of the esoteric type. We only know of a few, and so may not be able to give any comprehensive account of resources wasted in the 
drainage-pipes of voodooism. In 2008, the nation was stunned to know that about a billion Naira was paid for the services of Perekabowei Ogah, a 34-year-old, illiterate, voodoo practitioner by a 58-year-old, Nigeria's American-trained diplomat, Sam Edem, the then Chairman of the Niger Delta Development Commission (NDDC). According to Ogah, the voodoo consultant the services required of him included securing Sam Edem's job as NDDC Boss, killing or incapacitating Edem's rivals (Timi Alaibe and Governor Akpabio of Akwa Ibom State), and causing Goodluck Jonathan (then Vice President of Nigeria) to always obey Mr. Edem, and defend him against any plot forged to oust him from office. ${ }^{28}$

\section{Conclusion}

Men desire to live in peace and harmony, and to ensure that fracas is eliminated as much as possible, covenants are established. Whether the covenant is between two or more individuals as may be found in organisations like Judaeo-Christian circles, traditional religious or nature worship systems, secret societies, or between communities and/or nations, it has been widely held that covenants tend to command serious commitments; and that blood covenants demand irrevocable or indissoluble commitments. Organized groups based on blood oaths are primarily built to favour the parties to the covenants, not non-initiates as may be found in studies on secret societies, whether on university campuses or outside. ${ }^{29}$ Apart from this problem, we have learnt that blood covenant of the esoteric type (found in traditional religions and nature worship systems) is not a watertight enforcer of commitments by the human parties to the blood oath. In a country like Nigeria, with over 200 hundred ethnic groups, of diverse religious affiliations, it will be significant to adopt a covenant arrangement that has the good of every citizen at heart; but this cannot afford in the interim to be any blood covenant since that will denote an imposition of a particular creed upon the populace - a negation of a citizen's fundamental right to freedom of religion, a universally declared human right. Having in mind the complex constitution of Nigeria, any covenant adopted should possess values that are universalizable i.e. capable of being applied within the widest horizon. Some of these values include justice, equity, freedom, even as captured in the United Nations Universal 
Declaration of Human Rights (rights to self-determination, to liberty, to due process of law, to freedom of movement, to freedom of thought, to freedom of religion, to freedom of expression, to freedom of association, to peaceably assemble. These rights are fundamentally rooted in the idea of 'social capital' ${ }^{30}$ that consists of trust, social co-operation, and shared values. It seems to me that the West adopted these fundamental elements inspired by the JudaeoChristian outlook in formulating principles that make up the constitutions of different occidental nations and enabled its sociopolitical and economic integration and development.

*Emmanuel J. Ibuot, lectures in the Humanities Unit, School of General Studies \& Department of Philosophy, University of Nigeria, Nsukka.joeuwem@yahoo.co.uk; emmanuel.ibuot@unn.edu.ng 


\section{ENDNOTES}

1. Joseph C.A. Agbakoba, "Developing Appropriate Administrative Instruments for the African Cultural Environment," Uche 16 (2010): 7-8.

2. Onara O'Neil, "Enlightenment as Autonomy: Kant's Vindication of Reason" in Enlightenment and Its Shadows, eds. Peter Hulme and Ludmilla Jordanova (London and New York: Routledge, 1990), 189-190.

3. Emmanuel Ibuot, "Is an Unexamined Life not Worth Living? Problematizing the Foundation of Doing Philosophy," Uche 16 (2010): 132-139.

4. The Vatican News, Sunday March 20, 2011, 2.

5. G. E. Mendehall, "Covenant," The Interpreter's Dictionary of the Bible, $A-D$, eds. George Arthur et al (New York: Abingdon Press, 1962), 714.

6. F.O.C. Njoku, Essays in African Philosophy, Thought and Theology (Enugu: Snaap Press, 2002), 171.

7. E. W. Kenyon, The Blood Covenant (Oshodi: SP-Shepherd Publications, 1997), 9-14.

8. Kenyon, The Blood Covenant, 5ff.

9. Peter Kreeft, The Philosophy of Jesus (Indiana: St. Augustine's Press, 2007), 17.

10. Mr. Festus Abbah, Umu-Agali, Amallah, Udenu L.G.A., Enugu State. He is in his 50's.

11. A. N. Akwanya, Language and Habits of Thoughts (Nsukka: Afro-Orbis Publications, 1999), 21.

12. Akwanya, Language and Habits of Thoughts.

13. Simon Blackburn, The Oxford Dictionary of Philosophy (Oxford University Press, 2008), 272, 345.

14. The Vatican News, 2.

15. Anatole, Byaruhanga Akiki, "African Traditional Values are to be used as a Force for Human Development," African Theology in Progress, eds. J.T. Agbasiere and B.K. Zabajungu, Vols. 2 (AMACEA Publications), 56-57: In. Njoku, Essays in African Philosophy, Thought and Theology, 172.

16. Developments, Issue 35, 2006, 12-13; Newsweek, February 21, 2011, 13. 
17. The New Jerusalem Bible. Pocket Edition (London: Darton, Longman \& Todd, 1990), 1143.

18. David Ogbuelli, Rediscovering the Power of the Blood Covenant (Dominion Image Media, 2006), 119-120.

19. Rodney Stark, The Victory Of Reason (New York: Random House Trade Paperbacks, 2005); Loren Cunnigham and Janice Rogers, The Book that Transforms Nations: The Power of the Bible to Change any Country (Seattle: YWAM Publishing, 2007), 51-175; J.C.A. Agbakoba, "Ideology, Empirical Sciences, and Modern Philosophical Systems," JSRI 10 (2005): 116-125; F. K. Buah, West Africa and New Europe: A History for Schools and Colleges, Book Two, Macmillan Education Limited, London and Basingstoke, 1967, pp. 17-18.

20. Scott and Kimberly Hahn, Rome Sweet Home (Lagos: Criterion, 2000), 16,25-26,28; Charles J. Chaput, "The Sanctuary of Love," Catholic World Report, January 2000, 59-60.

21. Newsweek, February 21, 2011, 4.

22. Gbenga Akinfenwa, "Blood Oath Scandal," The Week, July 13, 2009, 14-18; Vincent Obia, "Ogun: Politicians in the Tradition of Voodoo," Thisday, Sunday, July 12, 2009, 105106.

23. Kenyon, E.W., The Blood Covenant, SP-Shepherd Publications, Oshodi, 1997, 5-13.

24. Idam, Jossy, "Inside Human Parts Market in Lagos," Sunday Sun, February 15, 2009, 7.

25. Little, L. K., Religious Poverty and the Profit Economy in Medieval Europe - Ithaca (New York: Cornell University Press, 1978), 4-7.

26. J.C.A. Agbakoba, "An Examination of the Impact of the Traditional Knowledge Systems and Culture on Contemporary Educational Achievement in Africa," Academic Co-operation with Africa: Lessons for Partnership in Higher Education, eds. E.W. Schamp and Stefan Schmid (Münster: Lit Verlag, 2008), 32.

27. Dante Germino, Machiavelli to Marx: Modern Western Political Thought (Chicago: The University of Chicago 
Ibuot: The Impact of Blood Covenant on Development in Nigeria

Press, 1972), 278.

28. Henri Umahi, "Expensive Juju: Can of Worms over Billion Naira Voodoo," August 09, 2008. In: NDDC Chairman's Juju Escapade (Full Story)

http://www.nairaland.com/nigeria/topic-158699.0.html (accessed August 09, 2011)

29. J.C.A. Agbakoba, "An Examination of the Impact of the Traditional

Knowledge Systems and Culture on Contemporary Educational Achievement in Africa," Academic Cooperation with Africa: Lessons for Partnership in Higher Education (Münster: Lit Verlag, 2008), 24-26, 31-32.

30. A. Roberts, "A Special Report on Migration," The Economist, January 2008, p.15; Jonathan Sacks, The Politics of Hope (London: Vintage, 2000), xv-xix. 